\section{Branko}

\section{Metzger-Šober}

samostalni istraživač

independent researcher

Laginjina 38

Rijeka, Hrvatska

branko.metzger@gmail.com

(iD)

orcid.org/0000-0002-0637-413X

Izvorni znanstveni rad

Original scientific paper

UDK / UDC:

069.9(497.5 Rijeka)"1925/1927”

DOI:

10.17685/Peristil.62.6

Primljeno / Received:

10. 3. 2019.

Prihvaćeno / Accepted:

21. 10. 2019.

\section{(cc) BY}

\title{
Bijenalne umjetničke izložbe u Rijeci 1925. i 1927. godine
}

\author{
Biennial Art Exhibitions in Rijeka \\ in 1925 and 1927
}

\begin{abstract}
APSTRAKT
Autor se ovim radom fokusirao na dvije od mnogih izlagačkih aktivnosti u Rijeci u razdoblju izmedu dvaju ratova, u vrijeme talijanske vlasti u čijoj su interpretaciji uključene aktualne regionalne, talijanske državne i šire europske političke prilike. Iznesen pregled ovih bijenalnih izložbi uveliko progovara o izoliranim, nepatvorenim umjetničkim trenucima unutar precizno određenoga vremena i prostora. Analizom prvih bijenalnih izložbi u Rijeci održanih 1925. i 1927. godine koje su raznovrsnošću obuhvaćenih iskaza umjetničkoga opusa iznimno širokoga i raznolikoga broja stvaralaca određene društveno-političkim okolnostima, potiče se na promišljanje o općoj zanemarenosti u sveopćem prihvaćanju Rijeke kao grada u stagnaciji po dolasku talijanske vlasti u njezinu meduratnom razdoblju.
\end{abstract}

\section{KLJUČNE RIJEČI}

Rijeka, aneksija, bijenale, međuratno, međunarodno, izložba

\section{ABSTRACT}

The paper focuses on two of the many exhibiting activities in Rijeka during the Italian rule in the interwar period, interpreted in the context of current regional, Italian state and wider European political circumstances. The presented overview of these biennial exhibitions largely speaks of isolated, authentic artistic moments within well-defined temporal and spatial framework. The analysis of the first biennial exhibitions in Rijeka held in 1925 and 1927, determined by socio-political circumstances through the variety of artistic expressions of an extremely broad and diverse number of artists, prompts a reflection on the general neglect of Rijeka as a city in stagnation in the period that followed the arrival of the Italian authorities.

\section{KEYWORDS}

Rijeka, annexation, Biennale, interwar, international, exhibition 
Sve donedavno kada je započelo sustavnije istraživanje povijesne građe, dio riječke povijesti obilježen gotovo dvadesetogodišnjim vladanjem Kraljevine Italije bio je malo ili nepotpuno interpretiran. ${ }^{1}$ Suvremeni istraživači još i danas pokušavaju stvoriti što pouzdaniju sliku o tom razdoblju na temelju istraživanja povijesnih i privatnih arhiva ne bi li metodom rekonstrukcije donijeli što nepristraniji uvid u kulturno stanje tog specifičnoga razdoblja. ${ }^{2}$ Ovaj rad ne obuhvaća sve likovno-izložbene aktivnosti u Rijeci, nego samo dvije, gotovo zaboravljene velike bijenalne izložbe priređene na tom prostoru, od kojih je jedna zbog svoje opsežnosti, broja izloženih radova i izlagača ostala i najvećom organiziranom izložbom u gradu Rijeci do današnjih dana.

Potpisivanjem Rimskoga ugovora 27. siječnja 1924. godine Rijeka je pripojena Kraljevini Italiji i osnovana je Kvarnerska provincija, koja je politički suverenitet stekla 22. veljače 1924. godine. Riječani su smatrali da je tim činom grad Rijeka ostvario svoj dugoočekivani povratak matici zemlji Italiji, koja će mu uzvratiti prosperitetom. U nadi njegova ponovnog gospodarskog i ekonomskog oživljavanja, nakon veoma dugoga razdoblja stagnacije uvjetovanoga povijesnim okolnostima medunarodnoga i političkog previranja, stanovnici Rijeke objeručke su prihvatili nove vladare smatrajući ih konačnim rješenjem za grad koji će tako dobiti dugo priželjkivani mir i blagostanje. Nadali su se ponovnom oživljavanju privrede koja je velikim dijelom zamrla u vrijeme Danuncijade. ${ }^{3}$ Oživljena bi industrijska proizvodnja potaknula već pomalo uspavana pomorska dobra i lučki promet, a Kraljevina Italija po tadašnjim je očekivanjima mogla ponovno Rijeku učiniti važnim lučkim i industrijskim središtem ovoga dijela jadranskog priobalja i Europe. No od samog se početka pokazalo da se ova romantičarska, nerealna očekivanja neće lako ni potpuno ispuniti.

\section{Prima Esposizione Fiumana Internazionale di Belle Arti 1925. godine}

U prvim godinama aneksije u Rijeci se počeo nazirati ekonomski i privredni uzlet do kojega je dolazilo s priljevom novoga talijanskog stanovništva koje je svoja, u pravilu upravljačka radna mjesta dobivalo unutar gradskih, političkih ili privrednih struktura. U novopriključenoj Kvarnerskoj provinciji talijanske su vlasti krenule s provodenjem niza sustavnih mjera kojima je cilj bio što skorije izjednačavanje političkoga i javnog života s onim u ostalim dijelovima Italije.

Jedna od njih je bila i organizacija Prve izložbe industrije, poljoprivrede i trgovine - I. Esposizione Industriale, Agricola e Commerciale, čije se otvaranje u Rijeci planiralo 25. kolovoza 1925. godine s ciljem prezentacije gospodarskih, turističkih i industrijskih aktivnosti, proizvoda grada i Kvarnerske provincije te cijele Kraljevine Italije. Osim nje, u isto vrijeme planirala se još jedna izložba, i to umjetnička.

Predsjedništvo Rimskoga bijenala uključuje se u njezino planiranje predlažući da bi ovu riječku umjetničku izložbu trebalo organizirati bijenalno jer bi se takvim ritmom pratio njihov Rimski bijenale, a čime bi riječka izložba postala njihovom umanjenom reprizom. Komentari iz tadašnjega tiska u više navrata i s velikom naklonošću naglašavaju moralnu i materijalnu potporu izložbe koju je dobila od rimske umjetničke, financijske i političke elite. ${ }^{4}$

Tako je riječki organizacijski odbor u lipnju 1925. godine krenuo s planiranjem u želji da je učini Prvom međunarodnom riječkom umjetničkom izložbom - Prima Esposizione Fiumana Internazionale di Belle Arti, pozivanjem, osim umjetnika predstavljenih na Rimskom bijenalu, i umjetnika iz susjednih zemalja - Kraljevine SHS i Mađarske. ${ }^{5}$ Planirano je da se izložba postavi u nekoliko sekcija u jednoj od najljepših gradskih palača u kojoj je bio smješten tadašnji Liceo scientifico. ${ }^{6}$

Izložbu su planirala dva organizacijska odbora: rimski i riječki. Rimski odbor mogao se pohvaliti najvećim imenima tadašnje rimske aristokracije u sastavu: Gino Antoni kao predsjednik te Valentino Leonardi, Duca Caracciolo di Forino, Duca di Girasole, Carlo Giovane, Principe Forino, Olindo Bitetti, Carlo Liporace i Giovanni Campomizzi. Riječki odbor bio je sastavljen od sljedećih članova: Riccardo Gigante, predsjednik, zatim Eduard Susmel, ing. Giuseppe Lado, ing. Luigi Morini, Oloferne Collavini, Mario de Hajnal i Carlo Ostrogovich. Za tajnika je izabran Mario de Hajnal. ${ }^{7}$ Krajem srpnja 1925. godine u Rijeci su se i službeno upoznali predsjednici dvaju organizacijskih odbora Gino Antoni i Riccardo Gigante te tom prigodom dogovorili o organizacijskim detaljima i datumu otvorenja izložbe, koje je bilo planirano za 15. kolovoza. ${ }^{8}$ Izložba je trebala ostati otvorena sve do 15. listopada 1925. godine.

Iz dostupnih tekstova može se utvrditi da je atmosfera u Rijeci onoga vremena odisala entuzijazmom 


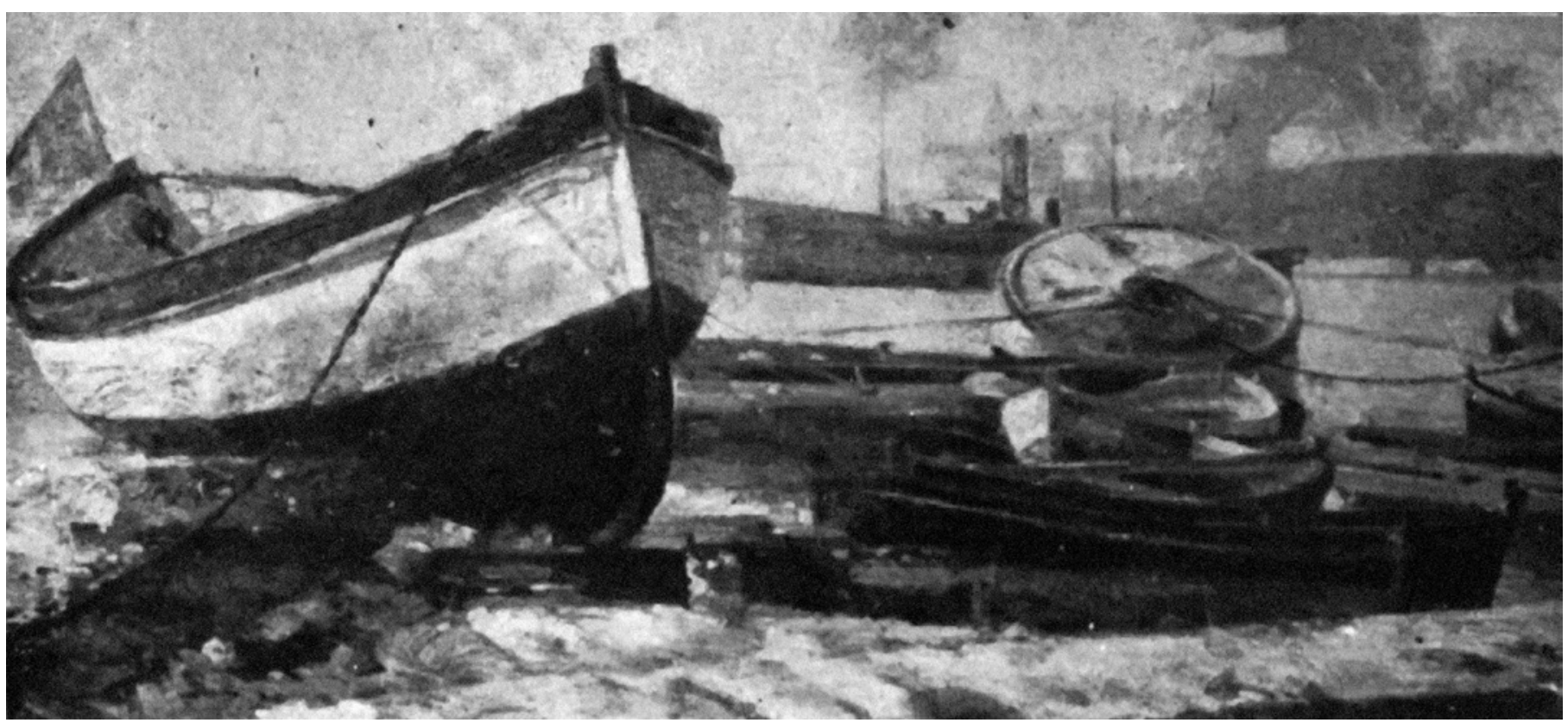

Carlo Ostrogovich, Riposo (In Porto di Fiume)

koji je zahvatio ne samo organizatore i umjetnike nego i cijeli grad. Polet i očekivanja bili su veliki. U povodu otvorenja Prve industrijske izložbe u Rijeci i proslave Pohoda iz Ronchija u organizaciji stranke Nazionale Fascista održavale su se mnoge sportske igre i zabave u gradu Rijeci i na kvarnerskoj rivijeri. ${ }^{9}$ Planirano je i svečano otvorenje operne sezone u Teatru Verdi gdje su se te sezone trebale izvesti najljepše talijanske opere kojima bi ravnao maestro Pietro Mascagni. ${ }^{10}$

U povodu ovoga umjetničkog događaja, istodobne industrijske i umjetničke izložbe te cijeloga niza popratnih manifestacija koje su se trebale održati, cijena željezničke karte reducirana je za 50\% za polaske sa svih stanica Kraljevine Italije prema njezinu sjeveroistoku - Rijeci. To je omogućio Il Governo Nazionale u svojoj patriotskoj namjeri da se poveća posjećenost riječkim događanjima. ${ }^{11}$ Umjetnički su radovi po organizacijskim pravilima trebali biti izloženi u nekoliko dvorana Licea scientifica; Sala Napoleonica bila je namijenjena onima s netom završenoga III. Rimskoga bijenala, djela mađarskih umjetnika trebala su se izložiti u Sali Ungherese, jugoslavenskih umjetnika i umjetnika regije Venecije Giulije u Sali Venezia Giulia, a djela riječkih umjetnika u Sali Arte Fiumana. U dodatnoj dvorani - Sala Storica
Fiumana - trebali su se izložiti artefakti iz riječke povijesti (povelje, manifesti, brošure i knjige) kojima bi se upućivalo na povijesnu pripadnost ovoga grada Kraljevini Italiji. ${ }^{12}$ Prema planu izložbe cijeli je događaj trebao kulminirati samostalnom izložbom velikoga talijanskog umjetnika Vicenza Cabiance.

Izložba Prima Esposizione Fiumana Internazionale di Belle Arti svečano je otvorena 25. kolovoza 1925. godine, s deset dana zakašnjenja u odnosu na prethodno definiran termin otvaranja. ${ }^{13}$ Historicističko monumentalno zdanje Licea scientifica bilo je za ovu prigodu okićeno zastavama i vrpcama, dok je prostrani atrij u kojem su se dočekivali uvaženi uzvanici iz političkoga i društvenog života Rijeke, Kvarnerske provincije i Italije bio ukrašen biljkama, cvijećem te detaljima koji su isticali talijansku državnost i riječku pripadnost Kraljevini Italiji. Goste pozvane na svečanost otvorenja izložbe dočekivali su članovi organizacijskih odbora, a otvorenje je između ostaloga popraćeno sljedećim riječima Gina Antonija, predsjednika rimskoga organizacijskog odbora: „... Umjetnici prisutni i odsutni, zahvaljujemo se na vašem prijateljskom doprinosu. Vi ste dobri prijatelji naših života i širokogrudna braća koji nas pratite kroz život otvarajući nam putove ove glazbe, 

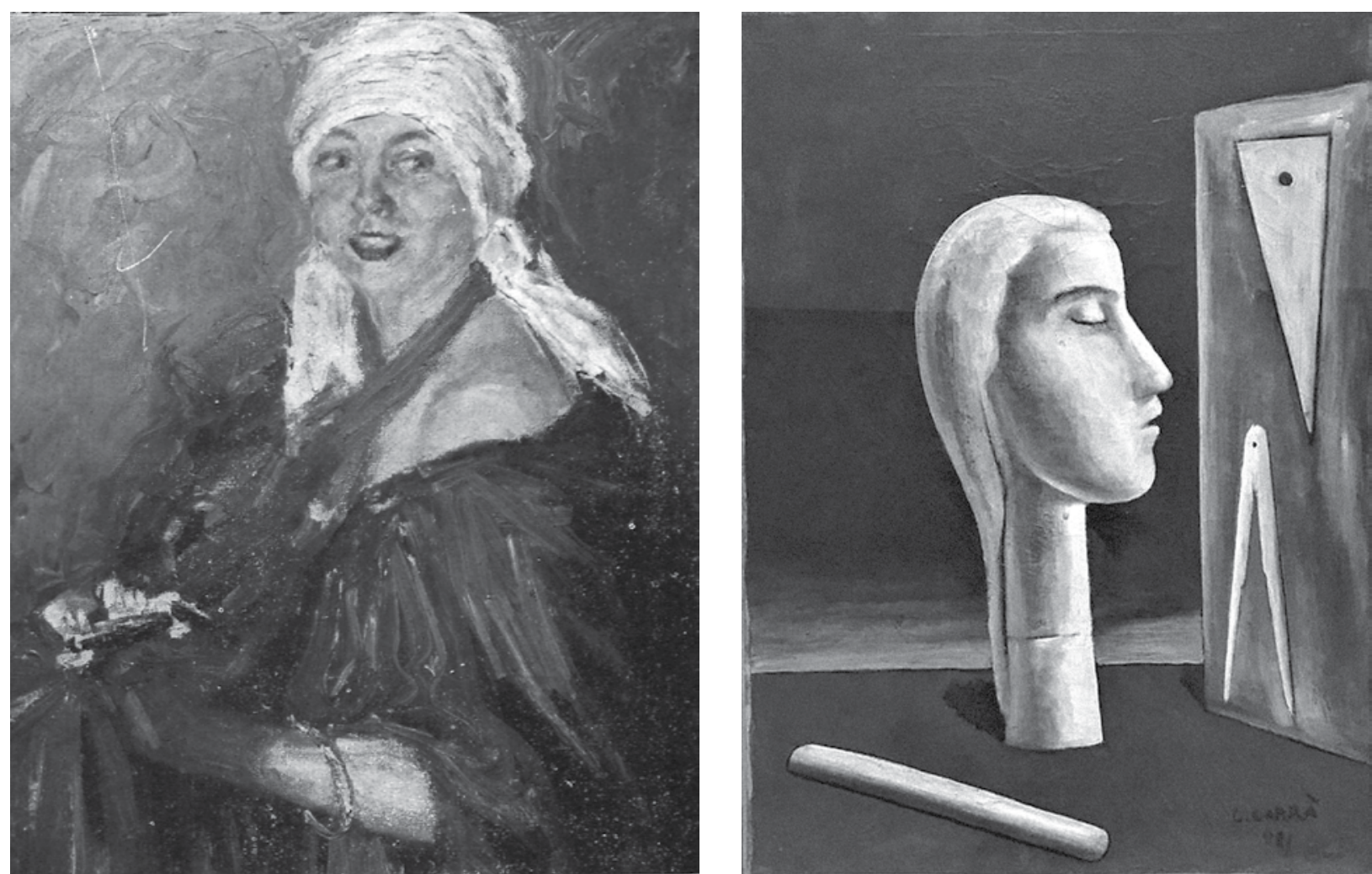

2 Mario de Hajnal, Ritratto di Signora (Giovinezza) Izloženo u sekciji Pittori Fiumani u sklopu Prima Esposizione Fiumana Internazionale di Belle Arti, Rijeka, 1925.

Mario de Hajnal, Ritratto di Signora (Giovinezza) Exhibited within the section Pittori Fiumani as part of the Prima Esposizione Fiumana Internazionale di Belle Arti, Rijeka, 1925

\section{Carlo Carrà, Solitudine}

Carlo Carrà, Solitudine

4 Carlo Carrà, L'amante dell'ingegnere Izloženo na samostalnoj izložbi Carla Carrà u sklopu Prima Esposizione Fiumana Internazionale di Belle Arti, Rijeka, 1925.

\section{Carlo Carrà, L'amante dell'ingegnere}

Exhibited at the Carlo Carrà solo exhibition as part of the Prima Esposizione Fiumana Internazionale di Belle Arti, Rijeka, 1925

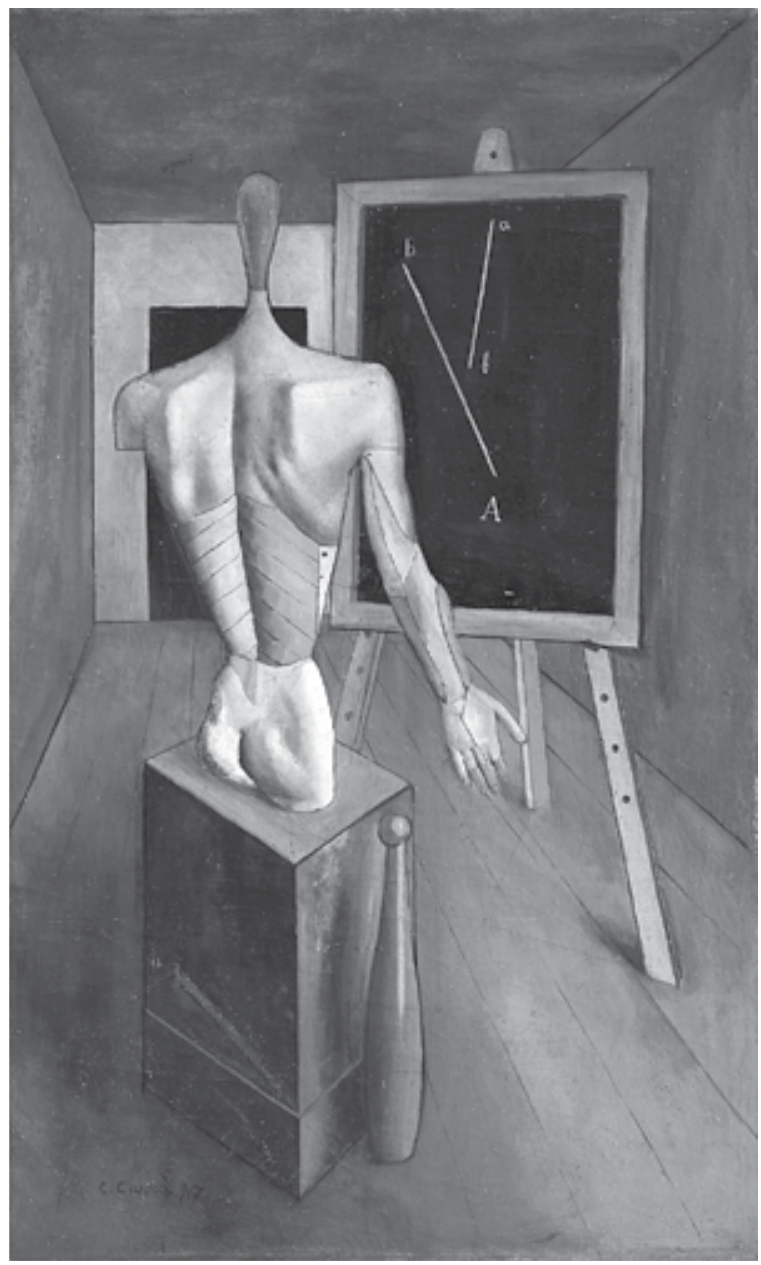


poezije, slikarstva, skulpture i arhitekture što u našoj duši budi ugodan osjećaj. Ja vam zahvaljujem u ime svih, bez obzira dolazite li iz Rima ili iz prelijepoga Napulja, Istre, Venecije, Jugoslavije ili Mađarske, pokazujući originalan biljeg umjetničke zrelosti prvoga reda. Ovo je svečani trenutak bratskoga ujedinjenja kroz nebesko plavetnilo umjetnosti koje se danas plemenito manifestira. Vama Commissario del Comune di Fiume, kao nositelju izložbe, povjeravam čast da je obznanim otvorenom u ime grada Rijeke nadajući se da će to biti prva od mnogih koje će uslijediti i da će svaka sljedeća biti sve bolja i bogatija." ${ }_{14}$

Za bolje razumijevanje važnosti ove izložbe kao velikoga kulturnog i umjetničkog događaja za Rijeku, treba se zadržati na konceptu izložbe i izdvojiti neke od izlagača i njihove radove. Pisati iz današnje perspektive o umjetnicima tog razdoblja i njihovim radovima otežano je zbog ograničene mogućnosti uvida u originalna izložena likovna ostvarenja. Likovna nam je kritika u ovom slučaju poslužila kao iznimno pozitivan medijator $u$ razumijevanju ovih izložbi. Poneki kritički osvrti suvremenika koje pratimo donose kronološku faktografiju, čime obogaćuju naše dosadašnje spoznaje o važnosti i društvenoj simbolici događaja te otkrivaju njegove specifične okolnosti. Unatoč visokom stupnju zanimanja, motiviranosti i nedvojbeno bogatoga neistraženog fundusa primarnih povijesnih izvora, moramo istaknuti neke ograde $u$ razmatranju dijela izvora, i to onih pri kojima ne nailazimo na potpis autora teksta što nas dovodi u nemogućnost procjene njegove vjerodostojnosti, te potom i do nužnoga razmatranja mogućega utjecaja takve atribucije na samu interpretaciju izvora.

Postav izložbe s 506 umjetničkih djela (slika, skulptura, grafika, crteža) 250 autora organiziran je u sedamnaest svijetlih i velikih dvorana netom obnovljene gradske palače u tadašnjoj ulici Via Ciotta, dok su grafike i crteži bili izloženi u za to, prema mišljenju kritičara, ipak neadekvatnim uvjetima - hodnicima bez dovoljno osvjetljenja. ${ }^{15}$

Prema dnevnome tisku, najviše interesa je izazvala Sala dei pittori fiumani koja se nalazila nasuprot raskošnoga stubišta unutar palače. Umjetnička produkcija ove male grupe riječkih slikara upozorava na ozbiljnost i visoku kvalitetu njihova rada. Enrico Fonda, riječki slikar poznat u slikarskim krugovima Italije, koji je tada boravio u Milanu, izlagao je prethodno na brojnim izložbama u Kraljevini Italiji, bio je prvi riječki slikar čiji je umjetnički rad prihvaćen i prezentiran na Venecijanskom bijenalu 1923. godine. Riječ je o autoru koji se isticao osobito u slikanju pejzaža. Iako je na ovoj izložbi sudjelovao s više radova, odabrao je samo dva s pejzažnim motivima što mu je, unatoč komplimentima, ipak bilo javno zamjereno. Osim ovih radova, Enrico Fonda izložio je i Ritratto di mia madre, Primavera te Nudo allo specchio. U istoj su dvorani bili izloženi i pejzaži Cornelija Zustovicha Riflessi i Armonie del mattino. Oloferne Collavini, umjetnik koji je stvarao s puno strasti i osjećaja, izložio je tada svoj, po ocjeni većine kritičara, najbolji rad - triptih Baccanale te slike Ninfa e satiro, Fiaba, Ritratto di Signora. Carlo Ostrogovich, potentni kolorist izvrsne čvrstine is naklonošću prema punim i jarkim tonovima, umjetnik sigurna i izravna poteza kista, izložio je Villiche nostrane, Tepori primaverilli, In porto a Fiume (sl. 1) i Boe e ancore. U trećoj dvorani Ugo Terzoli, udomaćeni rimski umjetnik s riječkom adresom, predstavio je ženski nježne i poetičnu slike L'Annunciazione, Farinata, osobito patetične u svojoj jednostavnosti - La canzone della trincea. U sljedećoj dvorani ističu se dvije slikarske kompozicije Umberta Gnate: jedna pod nazivom Una baccante, dok je druga alegorijska, $\mathrm{u}$ formi visokoga reljefa, prikazivala žensku figuru koja predstavlja Italiju u letu prema istoku, a u čijem su se podnožju vidjeli Istra i Kvarner. Mario de Haynal ovom je prigodom izložio tri djela, Carnevale, Ritratto di Signora (Giovinezza) (sl. 2) i Rammendando. Federica Blanda predstavila se dvama nježnim akvarelima studioznih kompozicija cvijeća Ortensie i Garofani, dok je Felice Fabro de Santi izložio tri akvarela visoke umjetničke kvalitete, Ritratto di Signora, Terra d'Istria i Costumi istriani dell'800. ${ }^{16}$

Do Sale dei pittori fumani, u prostoriji koja je nosila broj VI, samostalnu je izložbu imao Carlo Carrà, jedan od najvažnijih talijanskih slikara futurista. ${ }^{17}$ Izložena su trideset dva rada, koja su bila nešto sasvim novo za riječku publiku (sl. 3 i 4). Razumljivo je, stoga, nerazumijevanje posjetitelja na koje je ova izložba unutar izložbe naišla uzmemo li u obzir prostor i vrijeme te autorove originalne i istinski revolucionarne zamisli.

Prigodni katalog koji je u povodu ove velike izložbe tiskan (sl. 5), a čiju je naslovnicu vjerojatno oblikovao Ugo Terzoli, omogućuje detaljan uvid u popis svih sudionika likovne smotre i njihovih djela, ${ }^{18}$ pa tako i radova koje je Carlo Carrà ovom prigodom izložio u Rijeci. ${ }^{19}$ 
Talijanski slikari svoja su djela predstavili u deset dvorana, što zbog odabranih autora i izloženih djela nedvojbeno privlači pozornost. ${ }^{20} \mathrm{U}$ navedenom je mnoštvu, s osjećajem posebnoga poštovanja i razumijevanja njegove različitosti, unutar grupe talijanskih slikara, priređena i samostalna izložba slikara Vicenza Cabiance. ${ }^{21}$

Jugoslavenski slikari bili su okupljeni u dvorani XIV i izazvali ovom prilikom veliki interes. Smatra se da je ovo prvi put da se brojna i povezana grupa slikara iz susjedne države predstavila talijanskoj publici na jednom mjestu. ${ }^{22}$ Joso Bužan zastupljen je sa šest platna kojima je pokazao izvanrednu slikarsku ruku bogate autorske fantazije (sl. 6). Tu se našao i Mirko Rački, kao i Vladimir Filakovac s radom Siesta, po kritikama, efektnim djelom prevelike ugladenosti u kojem se nije mogao pratiti potez kista. Publici su se više sviđali pejzaži kojeisu imali realne slikarske vrijednosti kao što je bio njegov Paesaggio Viennese. Zamijećen je bio i Ritratto della Marchesa GambaiStojana Aralice, a zanimanje je pobudilo i platno Petra Pappa Golgota u duhu njemačkoga ekspresionizma. ${ }^{23}$ Otmjen stil litografije Milenka D. Gjurića iz ciklusa Il lavoro (sl. 7) svidio se publici i izazvao veliko zanimanje zbog tretiranja svjetla i velike preciznosti u izvedbi. Dostupni komentari ističu Gjurića kao osobu posebnoga umjetničkoga kova, ingenioznoga autora koji je istodobno bio slikar, pisac i novinar, nesvakidašnjih vrijednosti i postignuća. Iako se u tadašnjem dnevnom tisku navodi kako je Milenko D. Gjurić bio i na čelnoj funkciji tadašnje Likovne akademije u Zagrebu, što nije točan podatak, u širokom pregledu i osvrtima nakon završetka izložbe nailazi se na mišljenja da je upravo Gjurić zaslužio i više od kratke crtice o svojemu radu i životnom stvaralaštvu. ${ }^{24}$

U Sali Ungherese bila su izložena samo dva djela. Smatralo se da je to premalo s obzirom na to da se znalo kako je u Rimu i Milanu moderno madarsko slikarstvo tada bilo vrlo dobro poznato zbog velikoga broja slikarskih kompozicija koje su bile izložene u različitim prigodama tijekom vremena koje je prethodilo ovoj riječkoj izložbi. Opravdavajući se prekratkim rokom u kojem nisu mogli animirati svoje umjetnike, Mađari su na ovoj izložbi sudjelovali istaknutim, ali simboličnim brojem platna. Jedno od njih bio je rad Ivanyija Grunwalda, dok je drugo platno pripadalo Giuliju Benczuru. Osim izdvajanja slikara i opisa ostvarenja koje su prenijele dostupne tiskovine onoga vremena, ne smije se zaboraviti ni na sekciju crno-bijelih radova među kojima je bilo stotinjak crteža, bakropisa, radova suhom iglom, akvatinte, drvoreza i monotipija. Upravo u ovom dijelu pregleda istaknuti su najviše jugoslavenski umjetnici Joso Bužan, Milenko D. Gjurić, Đoka Mazalić s vedutama Bosne, Drago Vidmar te Vladimir Filakovac. Kroz neuvijene pohvale, iz ukupnoga opusa izložbe, izdvojilo se i pet vrlo ekspresivnih radova - gotovo karikaturalnih i autorskih macabre vizija Riječanina Riccarda Gigantea predstavljenih četirima crtežima tintom besprijekorne izrade i sugestivne fantazije. ${ }^{25}$

Skulpture na ovoj izložbi nije bilo mnogo, a ukupni stav prema tom umjetničkom izrazu svodio ih je na puku dekoraciju ${ }^{26}$ te su poput sobnih biljaka bile postavljene $u$ kutove interijera. ${ }^{27}$

Riječku je umjetničku izložbu posjetio veliki broj uglednika tadašnjega političkog i upravnog života Kraljevine Italije. Prilikom službenih posjeta gradu Rijeci u pratnji tajnika obaju organizacijskih odbora izložbe, Marija de Hajnala, uvaženi bi gosti obišli izložbu i pritom se naglašeno zadržali upravo na riječkim slikarima..$^{28}$ Velik interes potvrđuju kupnje umjetničkih djela o čemu je tisak ponosno informirao građanstvo Rijeke (sl. 8). ${ }^{29}$ Iako je ideja o produžetku likovne manifestacije dobila bezrezervnu potporu javnosti, riječka umjetnička izložba ipak je zatvorila svoja vrata 4. listopada 1925. godine. Zbog početka školske godine i nesavladivih teškoća u organizaciji nastave koja se održavala u toj zgradi, nije bilo načina da se trajanje ove manifestacije produži. U vrijeme održavanja školskih ispita izložba je u nekoliko navrata kratkotrajno zatvarana, što potvrđuje želju organizatora da ona traje što duže. ${ }^{30}$

Po zatvaranju ove izložbe u jednom od novinskih članaka ističe se dojam razočarenja riječkom javnošću koja za ovu umjetničku manifestaciju nije pokazala dovoljno interesa te je posjećenost bila ispod očekivane. Isticalo se kako je premalo toga učinjeno da bi se uputilo na mjesto održavanja izložbe. Smatralo se da mnogi potencijalno zainteresirani ljubitelji umjetnosti i osobe koje su se nalazile na odmoru u ovoj regiji nisu znali za ovaj događaj. ${ }^{31}$ Ovakav je komentar u potpunoj suprotnosti s jasno postavljenim ciljem organizatora kojima je, prema priznanju, uspjeh izložbe značio i veliku promidžbu Rijeke kao novoga kulturnog i umjetničkog centra Kraljevine Italije na vratima podunavskih zemalja. Je li osim navedenoga bilo i drugih razloga nezadovoljstva, ne ističe se. Ovakva situacija mogla bi se pojasniti 
PRIMA ESPOSIŻIONE FIUMANA INTERNAZIONALE DI BELLE ARTI - MCMXXV SOTTO 16 PATRONATO DEL MUNICIPIO DI FIUME

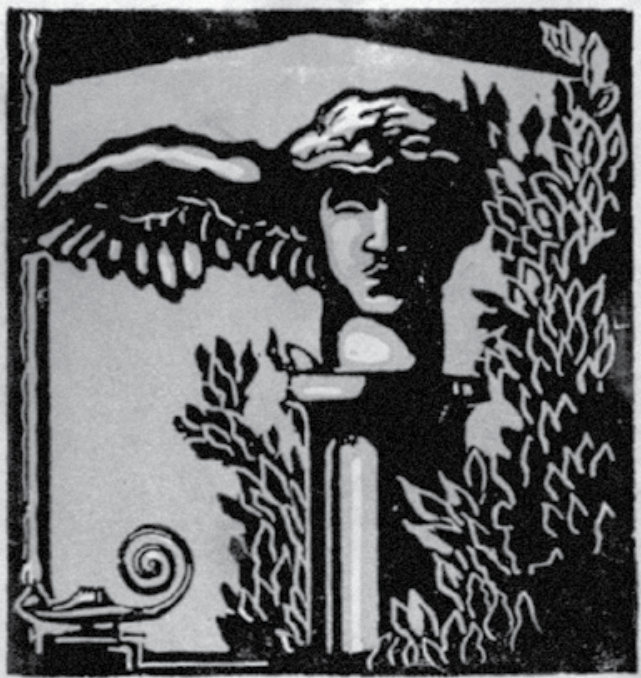

COL CONCORSO DEGLI ESPOSITORI

:: DELLA III BIENNALE ROMANA :; SEZIONE UNGHERESE SEZIONE JUGOSLAVA

\section{CATALOGO}

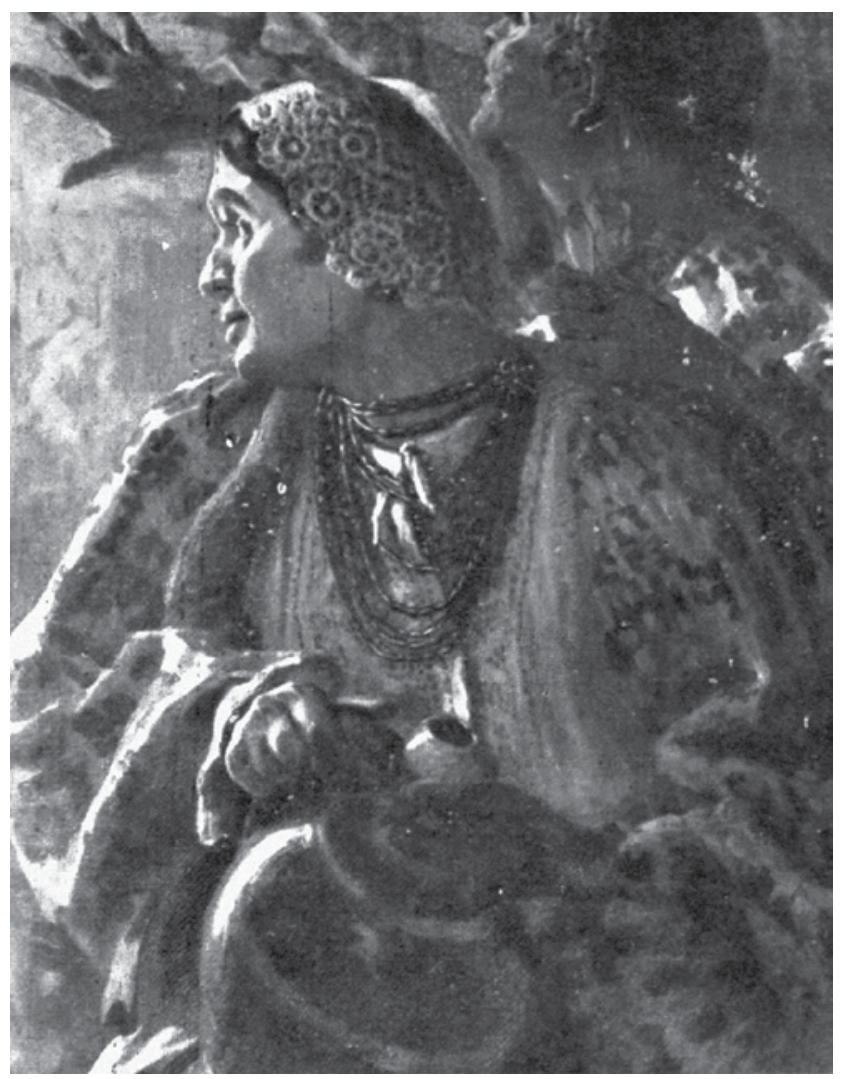

5 Prima Esposizione Fiumana Internazionale di Belle Arti, naslovnica kataloga, 1925.

Prima Esposizione Fiumana Internazionale di Belle Arti, exhibition catalogue cover, 1925

6 Joso Bužan, Ho cinque

Joso Bužan, Ho cinque

7 Milenko D. Gjurić, Lavoro

Izloženo u sekciji Jugoslavi u sklopu Prima Esposizione Fiumana Internazionale di Belle Arti, Rijeka, 1925.

Milenko D. Gjurić, Lavoro

Exhibited within the section Jugoslavi as part of the Prima Esposizione Fiumana Internazionale di Belle Arti, Rijeka, 1925

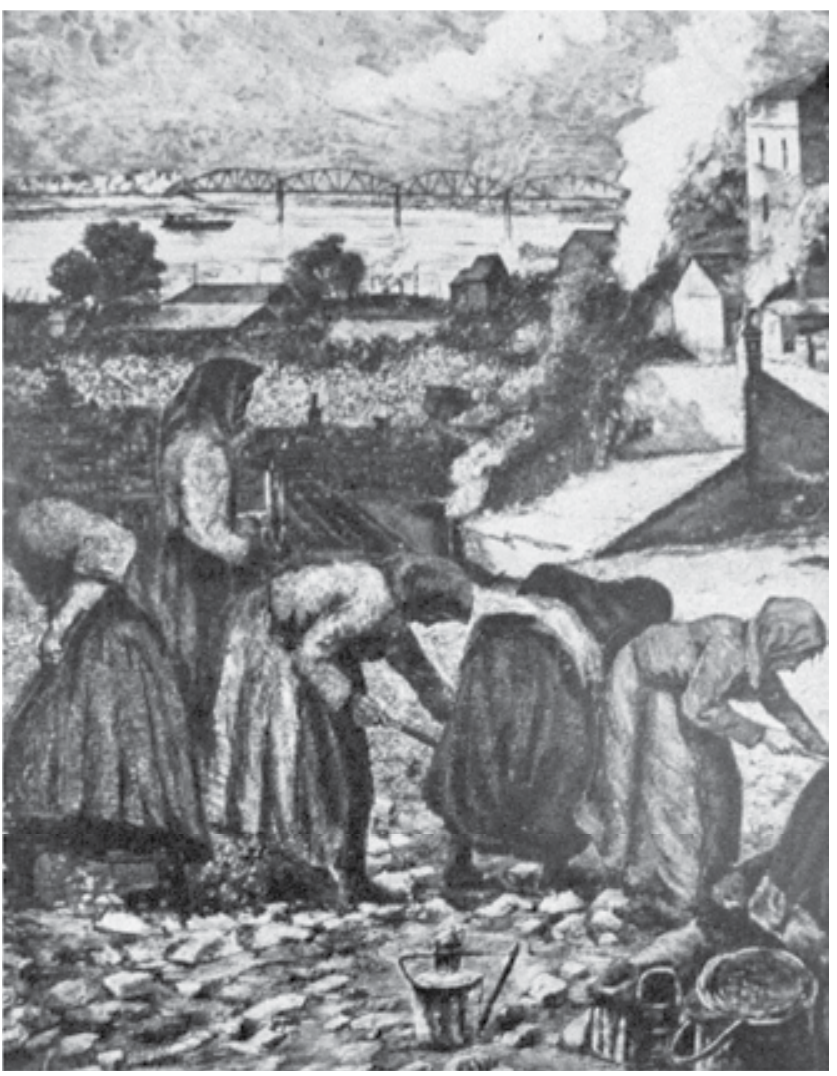




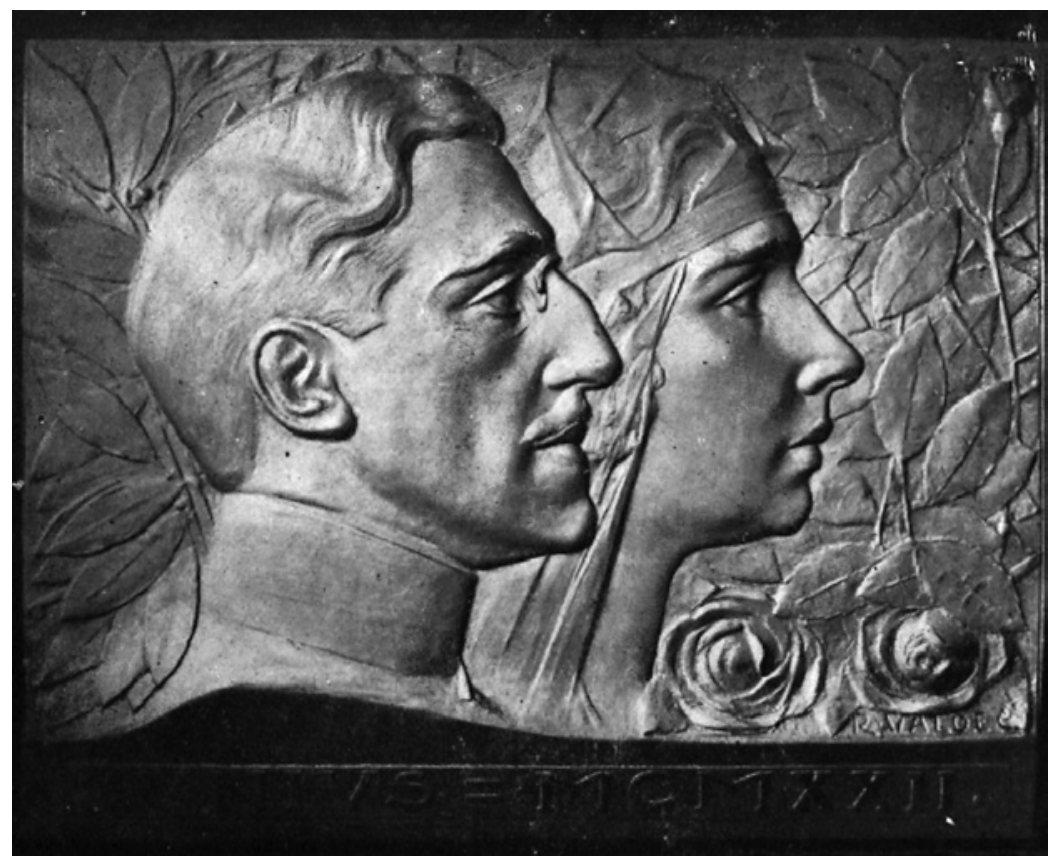

8 Rudolf Valdec, Re Alessandro I. e Regina Maria Bareljef u bronci izložen u sekciji Jugoslavi u XIV. dvorani na Prima Esposizione Fiumana Internazionale di Belle Arti, Rijeka, 1925.

Rudolf Valdec, Re Alessandro I. e Regina Maria Bronze bas-relief exhibited within the section Jugoslavi in hall XIV of the Prima Esposizione Fiumana Internazionale di Belle Arti, Rijeka, 1925

specifičnim povijesnim okolnostima u kojima se Rijeka nalazila u okviru novih političkih događaja. U doba kada se mijenjaju zastave, jezici i valuta, ni u manje specifičnim povijesnim situacijama ne može se očekivati potpuna nepristranost i apsolutno prihvaćanje novoga. Takva reakcija publike i izostanak očekivanoga posjeta može se pripisati i nenaviknutosti publike na događanja ovakvoga tipa i opsega.

\section{Seconda Esposizione Fiumana Internazionale di Belle Arti 1927. godine}

Krajem svibnja 1927. godine u riječkim je dnevnim novinama najavljeno kako se krenulo s pripremama za Drugu međunarodnu riječku umjetničku izložbu, II. Esposizione Internazionale di Belle $A r t i,{ }^{32}$ na kojoj će, kako su već tada najavili organizatori, publika moći uživati u umjetničkim djelima najboljih talijanskih umjetnika odabranih s 93. Esposizione della Società Amatori e Cultori di Belle Arti di Roma koja je u Rimu postigla uspjeh. ${ }^{33}$
Po uzoru na prethodnu izložbu održanu u Rijeci dvije godine prije, odlučeno je da će se ponovno predstaviti jugoslavenski autori, uz obećanje akademija likovnih umjetnosti iz Beograda i Zagreba da će u jugoslavenskoj sekciji biti zastupljeni odabrani umjetnici čiji će izbor pridonijeti najvišoj umjetničkoj razini događaja. Kako se ne bi ponovila pogreška s prethodne izložbe u odnosu na nesudjelovanje umjetnika iz drugih pozvanih zemalja, otpočetka se isticala jasna odlučnost organizatora da se poduzmu sve predradnje kako bi se to spriječilo. Predsjednik talijanskoga dijela organizacijskoga odbora Gino Antoni dobio je tijekom boravka u Budimpešti vijest, koju je potom i žurno prenio, da je vlada Mađarske službeno istaknula svoje sudjelovanje na izložbi u Rijeci. Za razliku od prošloga nastupa Mađara koji su se na Prvoj međunarodnoj riječkoj umjetničkoj izložbi predstavili malim brojem umjetnika, za ovaj su put najavili djela najboljih mađarskih slikara koji su se u zadnjih desetak godina istaknuli $\mathrm{u}$ europskim avangardnim umjetničkim pokretima i grupama. ${ }^{34}$

Ponovno okretanje k umjetničkim krugovima podunavskih zemalja te pozivanje njihovih umjetnika na sudjelovanje u ovoj izložbi znak je da je postala važnim događajem u umjetničkom, kulturnom i političkom smislu. Prema dostupnim tekstovima kritike i kroničara jasno je iskazana vjera kako se na njezinim temeljima razvija nada stvaranja čvrstoga kulturnog i umjetničkog mosta koji bi preko Rijeke vodio od Italije prema Srednjoj Europi. Ovaj most suvremenici su redom pozdravljali i doživljavali višeznačno: u ekonomskom, općeintelektualnom i, posebno, umjetničkom smislu. Da to postaje stvarnost, pokazuje i interes za sudjelovanjem Bugarske, Rumunjske, Rusije, Čehoslovačke i Poljske na ovoj umjetničkoj manifestaciji. ${ }^{35}$

S obzirom na ponovno održavanje velike Internacionalne izložbe industrije i poljoprivrede u Rijeci, za koju je već unaprijed bilo sigurno da će biti izvrsno posjećena i privući brojne posjetitelje iz cijele Kraljevine Italije te drugih krajeva Europe, riječka se II. Esposizione Internazionale di Belle Arti trebala s ciljem koordinacije izmedu ta dva događaja otvoriti 1. kolovoza i ostati otvorenom do kraja rujna 1927. godine. Zbog porasta opsega izložbe i prijava većega broja sudionika morao se potražiti novi, prikladniji i veći prostor od $L i$ cea scientifica. Kako u gradu Rijeci nije bilo moguće pronaći lokaciju koja bi se prenamijenila u 
isključivo izlagački prostor te s obzirom na ljetno razdoblje godine, izbor je ponovno pao na školsku zgradu. Sada je bila odabrana zgrada djevojačke škole Palazzo delle Scuole Municipali Emma Brentari čije su učionice bile veće i, po procjeni organizatora, prikladnije za izlaganje najavljenih umjetničkih djela. ${ }^{36}$

U dnevnim tiskovinama drugih gradova šire regije pisalo se o ovoj velikoj umjetničkoj izložbi i najavljivalo njezino otvorenje za prve dane kolovoza. ,... Riječka izložba je jedna od najvažnijh umjetničkih izložbi koja je ove godine realizirana u Italiji, pa tako i u Europi. Cilj ove izložbe je predstavljanje talijanske umjetnosti i umjetnosti država s kojima graniči na sjeveroistoku. Službeno se izložbi priključila Mađarska, kao i Jugoslavija s povećim listama umjetnika odabranih od strane prof. Gjurića, a uspostavljeni su i kontakti o mogućem sudjelovanju umjetnika iz Bugarske, Poljske i Čehoslovačke. ... riječi su kojima je događaj najavio zagrebački Morgenblatt, a prenijela riječka La Vedetta d'Italia." ${ }^{77}$ Slične tekstove pratimo i u dnevnim novinama drugih velikih gradova srednje Europe. Tako Narodny Listy iz Praga blagonaklono najavljuje događaj, dok mađarske dnevne novine naglašavaju važnost i veliku nacionalnu posvećenost organizaciji izložbe..$^{38}$

Zahvaljujući dobrim kontaktima s članovima organizacijskoga odbora izložbe, novinarima je bio omogućen razgled izložbenih prostorija prije otvorenja. ${ }^{39}$ Prostorije su, kako navode u tisku, bile u svakom svojem dijelu ispunjene užurbanom aktivnošću radnika koji su postavljali posljednje od brojnih izložaka. U izložbeni prostor škole Emma Brentari pristiglo je oko tisuću radova velike vrijednosti koji su bili raspoređeni u šesnaest dvorana predvidenih za ostvarenja talijanskih umjetnika, osam dvorana za radove mađarskih umjetnika, dvije dvorane za radove jugoslavenskih umjetnika, dok je jedna dvorana ugostila djela ostalih međunarodnih umjetnika. ${ }^{40}$

Izvori pružaju podatke o zamjetnoj i sustavnoj marketinškoj aktivnosti koju su, za razliku od dvije godine prije, organizatori ovom prilikom poduzeli. ${ }^{41}$ Tako su oko izložbene palače bili postavljeni smjerokazi dok su brojni plakati diljem centra grada iscrpno informirali i usmjeravali posjetitelje prema izložbi. Nakana organizacijskoga odbora bila je da se tako isprave pogreške s prethodne izložbe, poveća posjećenost, ali i na primjeren način dočeka umjetnike koji su dolazili iz različitih dijelova Europe. Organizator je želio dovesti u Rijeku sve dostupne autore koji su se radovima prezentirali na izložbi, što je dobilo nepodijeljenu potporu svih relevantnih subjekata i cijele javnosti. Nazočnost velikih umjetničkih imena na izložbi i bez realnoga ostvarenja kontakta znatnijega broja posjetitelja s njima dalo bi nemjerljiv obol promociji samoga događaja, pobuđivanja opće znatiželje i pozornosti medija te visokoga ukupnog interesa gradske, talijanske, ali i medunarodne javnosti.

Izložba je otvorena 7. kolovoza 1927. godine..$^{42}$ Ugodno iznenadenje posjetiteljima bila je unutrašnjost škole koja je bila potpuno preuređena. Po opisu novinara, ulazni atrij izgledao je kao park, uređen biljkama postavljenim duž skalinade koja je vodila do mezanina, girlande od lovora obavijale su kolone i nastavljale se penjati po zidovima ukrašavajući glavni ulaz na kojem su bile postavljene nacionalne zastave zemalja sudionika. Izložbene su dvorane bile pripremljene za izlaganje u skladu s vrhunskim standardima vremena - dvotrećinska visina zidova prostorija i hodnika bila je prekrivena sivom tkaninom ne bi li se neutralizirala pozadina i time istaknula ljepota umjetničkih djela i njihove opreme. Prozori su u dvoranama bili napola zatamnjeni, a u dvoranama izmedu prozora i u hodnicima bile su postavljene klupe. ${ }^{43}$

Nakon ulaza, lijevo na mezaninu u prvoj dvorani, bila je postavljena retrospektiva s petnaestak djela u raskošnim okvirima netom preminuloga Paola Sale, jednoga od najvažnijih talijanskih akvarelista 19. i 20. stoljeća. Prva od četiriju sljedećih dvorana bila je posvećena nezavisnim umjetnicima koji nisu pripadali nijednoj od nacionalnih grupa, a obilježeni su bili pridjevom međunarodni. U daljnjim su dvoranama bili izloženi talijanski umjetnici: Ceracchini, Pirandello, Francalanci čije su slike predstavljale posljednje tendencije u talijanskoj umjetnosti. Izmedu njihovih radova nalazile su se i slike drugih, iznimno poznatih umjetnika mlade generacije talijanske umjetnosti kao što su Domenico Quattrociocchi, Giovanni Guerrini, Giuseppe Apre, Dante Comelli, Renato Javarone, De Bernardi, Carlo Ferrari i Domenico Lomedi. Na istome katu izložba se nastavljala u Sali Eroiche u kojoj su izložene radove imali Giovanni Marchig (sl. 9) i Ugo Ortona, grupa Labronico s G. C. Vinzijem, Pliniom Nomellinijem i Gianninom Marchigom. U sljedećoj dvorani koja je nosila ime Sala degli artisti Piemontesi izlagali su Nicola Arduino, Amleto Cataldi (sl. 10), Felice 

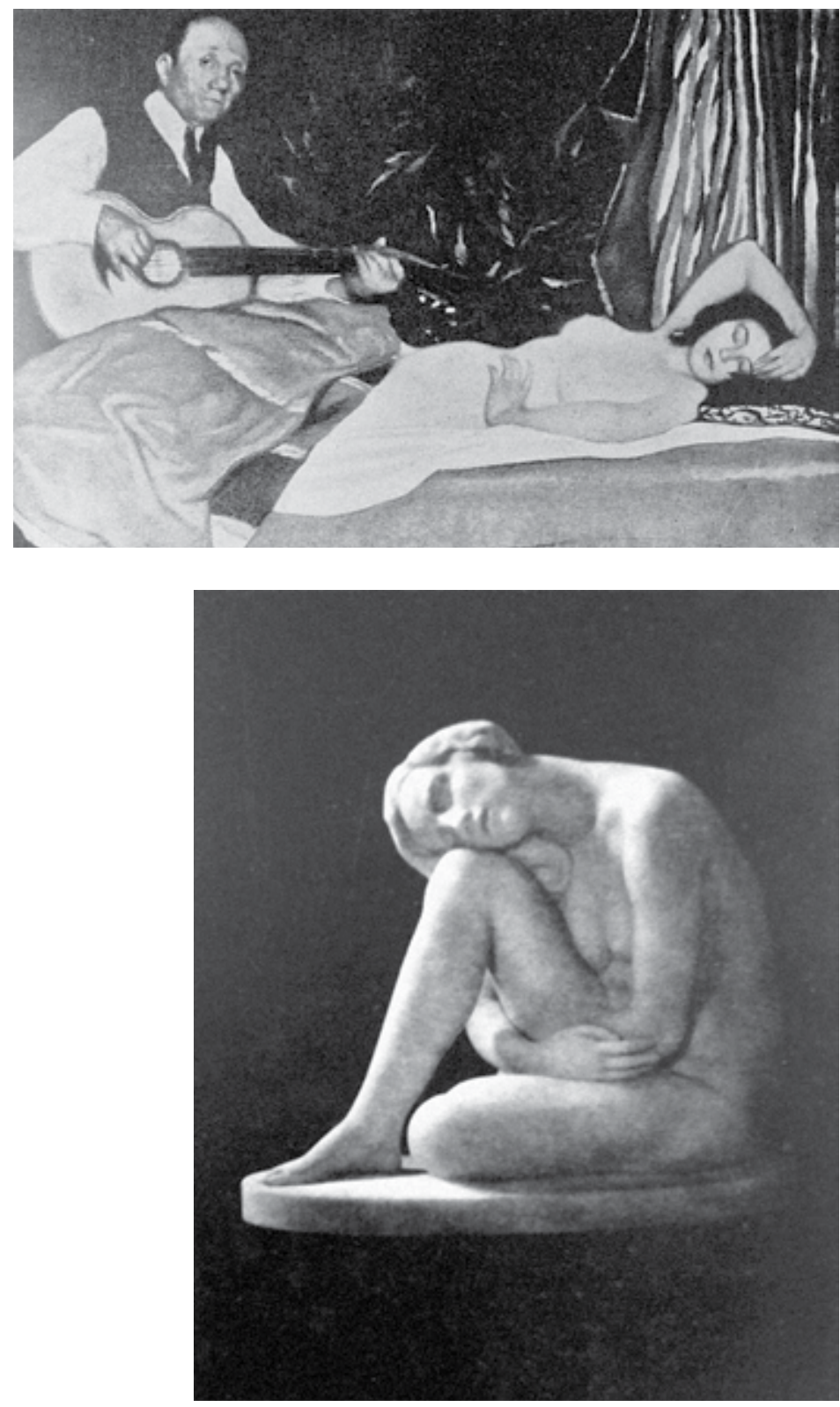

9 Giannino Marchig, Momento musicale Izloženo u sekciji Gruppo Labronico e Gruppo dell'Eroica u sklopu izložbe Seconda Esposizione Fiumana Internazionale di Belle Arti, Rijeka, 1927.

Giannino Marchig, Momento musicale Exhibited within the section Gruppo Labronico e Gruppo dell'Eroica as part of the Seconda Esposizione Fiumana Internazionale di Belle Arti, Rijeka, 1927

10 Amleto Cataldi, La donna dormiente Izloženo u sekciji Piemontesi na Seconda Esposizione Fiumana Internazionale di Belle Arti, Rijeka, 1927.

Amleto Cataldi, La donna dormiente

Exhibited within the section Piemontesi at the Seconda Esposizione Fiumana Internazionale di Belle Arti, Rijeka, 1927
Vellan, Giulio Boetto, Guido Montezemolo s radovima inspiriranim ljepotama regije Piemonte, a u istoj su dvorani bile izložene i tri drvene skulpture Michelea Guerrinija.

Na samome kraju, dvije dvorane posvećene su jugoslavenskim umjetnicima, kako navode u tisku - slikarima Slavenima, zastupljenim i grafičkim radovima, među kojima su izlagali: Milenko D. Gjurić, Zvonimir Lukinović, Rajko Šubic, Vlaho Pečenac, Hinko Smrekar, Saša Šantel, Elko Justin (sl. 11), Anton Kuman, Ivan Kos, Vjera Bojničić, Ladislav Kralj-Međimurec, Ivka Orešković, Joso Bužan, Viktor Šipek. ${ }^{44}$

U mađarskom dijelu izložbe u devet dvorana bilo je izloženo više od 300 ulja na platnu, akvarela i tempera koje su davale potpuni uvid u suvremenu mađarsku likovnu umjetnost (sl. 12). Kako se navodilo, osobito su se zanimljivima činila djela koja su predstavljala ljepote glavnoga mađarskog grada te djela u dvoranama avangardnoga slikarstva. Kao i tijekom prethodne izložbe, u jednoj od dvorana s 46 predmeta prezentirala se manufakturna radionica porculana Herend, prepoznata po svojoj rafiniranoj izradi.

U posljednjoj su dvorani prvoga kata bili izloženi slikari iz međunarodne sekcije među kojima su bile izložene slike s prikazima stare Rusije - Leonida i Rime Brailovski te četiri slike sardinijskoga umjetnika Melkiorra Melise. U hodniku su bile izložene grafike, drvorezi, litografije i bakropisi poznatih autora medu kojima i Angelo Rossini, Sansalvadoli, Scaramucci, Dario Neri. Tu su bili De Ströbelovi radovi u temperi, drveni reljefi Adolfa Boldinija i reljef u koži Marija Marina. ${ }^{45}$

Na drugom katu izlagali su riječki umjetnici. Ulaz na ovaj kat bio je iznimno inovativno riješen prema opisu kritike: „,... ukrašen jako uspješnim kistom i ugljenom fijumanskoga slikara Romula Wnousceka koji je dobio nagradu na natječaju Accademia di belle arti u Budimpešti." ${ }^{66}$ U prvoj dvorani drugoga kata izloženi su radovi grupe De Cordi Latii te grupe Marchigiano s najslavnijim imenima talijanskoga suvremenog slikarstva: Sartori, Cromaldi, Ortolani, Cecconi. U iduće dvije dvorane - u Sali del Gruppo Flegreo slijede druga najveća imena moderne talijanske umjetnosti: Mancini, Irolli, Fabricatore, Casciaro, Colucci i Gemito sa skulpturama u bronci, a u Sali dei Fiumani nalazile su se slike Leonide Villani, Carla Ostrogovicha, Marije Arnold, Mirande Raicich, Marcella Ostrogovicha, Marija Blasicha, Remigia Mihicha, Emilija Weisza, Marija de Hajnala, 
Cornelija Zustovicha, Ladislaa de Gaussa, Federice Blande, Bruna Anghebena, Uga Terzolija, Oscara Knollseissena, Romola Wnousceka te dvije Balestrierijeve skulpture.

Slijedile su talijanske dvorane - Sala degli Emiliani i dvije Sale dei Veneti: u prvoj se skupini među brojnim, redom poznatim izlagačima isticao Mornis Pictor, koji je predstavio tri slike dostavljene iz Galerije Valili Podesta iz Bologne, dok su u venecijanskoj grupi bili Parin, Pomi, Wolf-Ferrari i Levier. U hodniku su još bili izloženi radovi grafičara iz Rijeke Cesarea Conighija, koji je predstavio vizure staroga grada, a uz njega su bili i radovi rimske grupe grafičara te nekoliko njihovih skulptura. Na samom kraju izložbenoga slijeda bili su prikaz arhitektonskoga projekta autora Melonija i keramike autora Retrodija i Riječanke Irene Wittek. ${ }^{47}$ Od otvorenja izložbe interes publike za Drugu međunarodnu riječku umjetničku izložbu kontinuirano je rastao. Pokrenuta je inicijativa kojom bi publika mogla sudjelovati u dodjeli medalje za najboljega umjetnika i umjetničko djelo izložbe. Istina, inicijativa nije bila bez protivnika, pa su njome bile potaknute polemike oko načela i mogućnosti same kvantifikacije umjetnosti te kriterija za izbor najbolje slike, skulpture i umjetnika. Inovativnost promotivnih aktivnosti ilustrirao je prijedlog da glasački listići uđu u nagradnu igru te da se po završetku izložbe izvuče nekoliko ulaznica koje će kao nagradu dobiti po jedno umjetničko djelo s izložbe, što je i učinjeno. ${ }^{48}$

Osim brojnih građana, izložbu u Rijeci posjetili su i mnogobrojni uglednici, karakterizirajući je time kao izniman društveno-politički događaj. ${ }^{49} \mathrm{U}$ procjeni uspjeha izložbe i u želji za objektivizacijom njezinih učinaka, osim brojnosti publike koja je po danima varirala od 500 do 800 posjetitelja, treba naglasiti da uspjeh izložbe dokazuju i brojni otkupi izloženih djela. ${ }^{50}$ Danas, osim podatka o otkupima umjetničkih djela s ove i prethodne izložbe, a sa svrhom da budu institucijsko vlasništvo, teško je utvrditi njihov daljnji put. Umjetnička djela koja su bila u institucijskom vlasništvu, a koja bi za ovakvu rekonstrukciju svojom važnošću i brojnošću predstavljala nezaobilazan izvor informacija, u društveno-političkim i ratnim okolnostima velikim su dijelom nestala, a pokušaj pronalaženja njihovih tragova nailazi na barijere različitih inozemnih institucija i pojedinaca.

Izložba (sl. 13) je svečano zatvorena 8. rujna 1927. godine. Tom je prigodom ministar u vladi zadužen za područje kulturne suradnje (Ministro
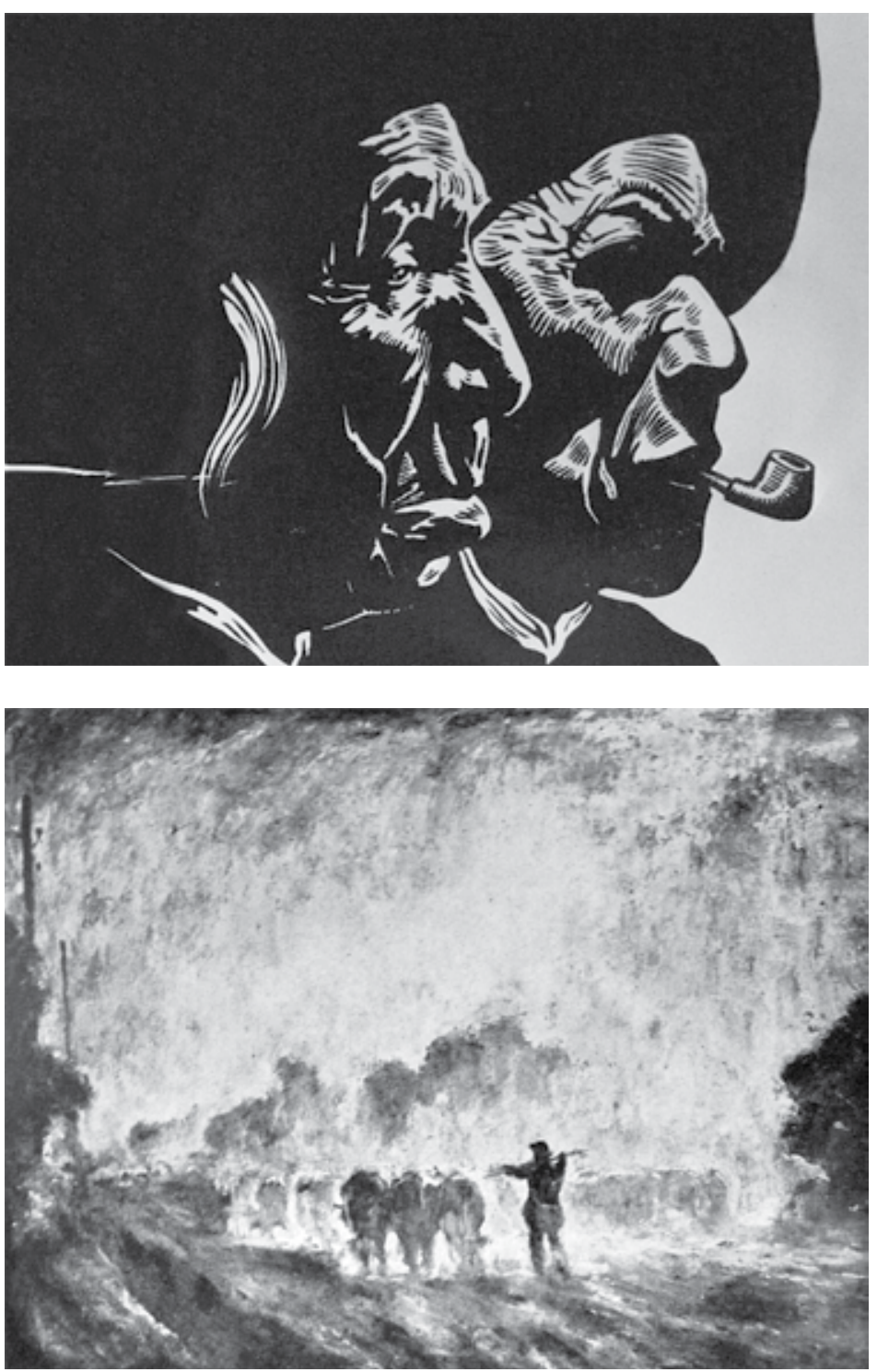

11 Elko Justin, Vecchi

Izloženo u sekciji Internazionale (Pittori e sezione ufficiale dell'Associazione Jugoslava artisti incisori) - Jugoslavi na izložbi Seconda Esposizione Fiumana Internazionale di Belle Arti, Rijeka, 1927.

Elko Justin, Vecchi

Exhibited within the section Internazionale (Pittori e sezione ufficiale dell'Associazione Jugoslava artisti incisori) - Jugoslavi at the Seconda Esposizione Fiumana Internazionale di Belle Arti, Rijeka, 1927

12 Bela Ivanyi-Grünwald, Sole e polvere Izloženo u sekciji Gli Ungheresi - Opere concesse dal Museo della Città di Budapest na izložbi Seconda Esposizione Fiumana Internazionale di Belle Arti, Rijeka, 1927.

Bela Ivanyi-Grünwald, Sole e polvere

Exhibited within the section Gli Ungheresi - Opere concesse dal Museo della Città di Budapest at the Seconda Esposizione Fiumana Internazionale di Belle Arti, Rijeka, 1927 


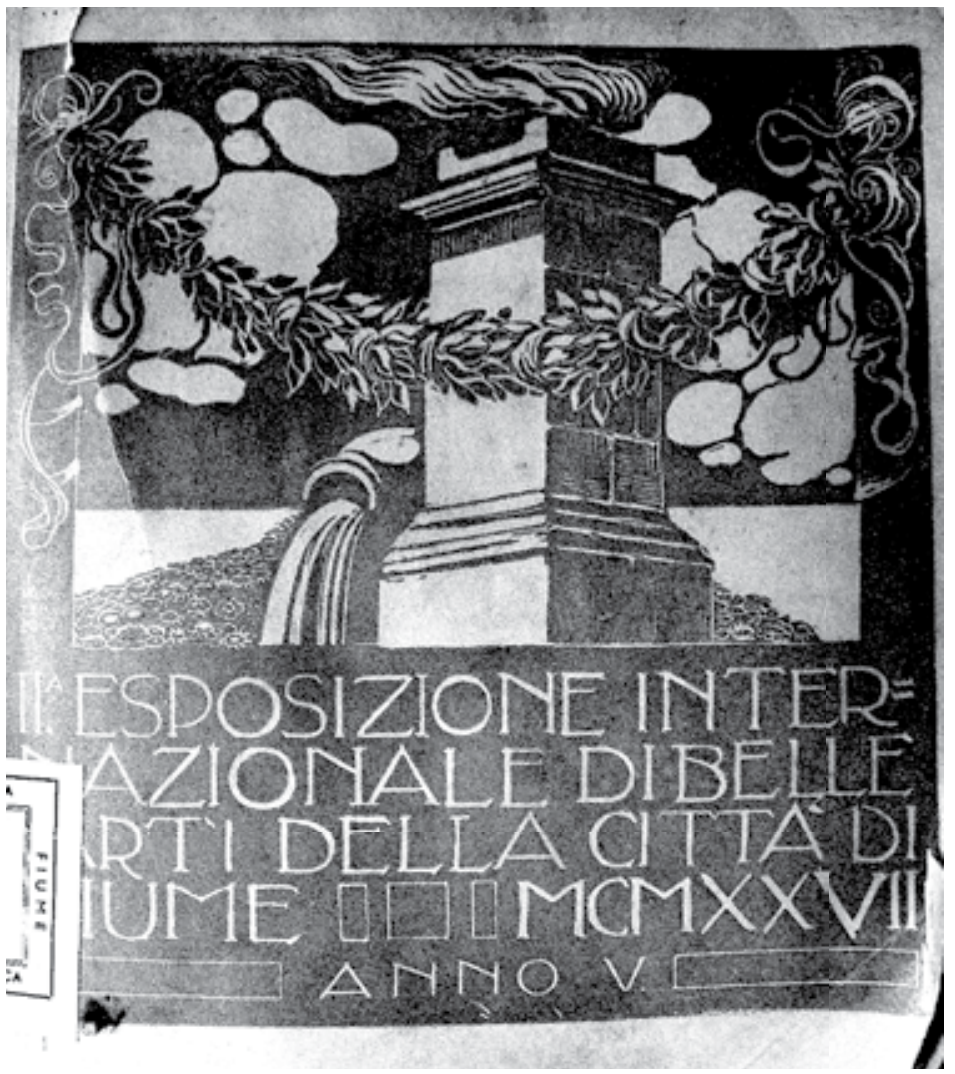

13 II. Esposizione Internazionale di Belle Arti della città di Fiume, naslovnica kataloga, 1927.

II. Esposizione Internazionale di Belle Arti della città di Fiume, exhibition catalogue cover, 1927 della Pubblica Istruzione), uputio u Rijeku Gina Fogolarija, direktora Accademije delle Belle Arti di Venezia, i aktualnoga konzervatora srednjovjekovnih spomenika Triju Venecija (Conservatore dei Monumenti medievali delle Tre Venezie) kao svoga osobnog izaslanika. Navedenoj je ceremoniji zatvaranja prisustvovalo i visoko izaslanstvo Mađarske na čelu sa senatorom i poznatim književnikom Francescom Hercegom čija je funkcija u tadašnjim medijima definirana kao generalni tajnik Akademije lijepih umjetnosti iz Budimpešte (Segretario Generale delle Belle Arti di Budapest), a uz njega je bio nazočan i Kartesz, državni podtajnik za kulturu i javnu naobrazbu Mađarske (Sottosegretario di Stato per il Culto e la Pubblica Istruzione d'Ungheria). ${ }^{51}$

S obzirom na veliki broj izlagača i važnost djela različitih tendencija i škola, manifestacija je u konačnici zaista mnogostruko nadmašila onu održanu dvije godine prije. U povodu ovoga važnog dogadaja Rijeka je, po prosudbi suvremenika, tako postala mostom koji je ujedinio umjetnički život Italije i podunavskih zemalja, a što je i bio cilj organizacijskoga odbora. Dodatno ističu kako je grad Rijeka na najpovoljnijoj geografskoj poziciji koja omogućava umjetničku razmjenu: istok Europe je iz ekonomskih i prometnih razloga orijentiran prema Jadranu, a grad Rijeka predstavlja njihova vrata prema Zapadu. Prerastanje ovakve povezanosti na kulturno-umjetničku razinu te puna integracija regije s mnogostrukim pozitivnim učincima na društveni život u cjelini komentari su koje nalazimo u zapisima iz razdoblja nakon zatvaranja izložbe. ${ }^{52}$

Prema novinskim kritičkim osvrtima teško je pomnije sagledati kompletni doseg i tendencije umjetničkih radova izloženih na objema izložbama. Kritički osvrti uglavnom su navodili samo sudionike ove velike izložbe te generalizirali sveukupni dojam izloženih radova po dvoranama $s$ iznimkom izdvajanja pojedinačnoga umjetnika i njegova djela. Kritika se najviše bavila aspektom viđenja događaja kao moguće inauguracije Rijeke kao novog centra okupljanja talijanskoj publici manje poznate ili potpuno nepoznate umjetničke produkcije podunavskih zemalja te njezina utjecaja na društveni život samoga grada. ${ }^{53}$

Brojni napori koji su se ulagali kako bi izložba nadvladala izolirani umjetnički događaj i bila iskorištena za što veću javnu promociju pripadnosti Rijeke kulturnom krugu Italije te isticanje nove uloge grada na globalnoj europskoj 
kulturno-umjetničkoj i socio-ekonomskoj karti Europe, opisanim su detaljima dodatno potvrdeni. Ovom izložbom bili su zadovoljeni ciljevi koje je organizacijski odbor postavio, a odnosili su se na sudjelovanje što većega broja važnih autora, njihovo predstavljanje po nacionalnoj i regionalnoj zastupljenosti, organizaciju galerijskoga prostora u skladu s najvišim kriterijima vremena, što upućuje na činjenicu da su aktivnosti odbora za to vrijeme bile na tragu suvremenoga pristupa. ${ }^{54}$ Među brojnim pratećim tekstovima u povodu zatvaranja izložbe ne mogu se izostaviti glorifikacijski osvrti te jednoglasne ocjene talijanskih kritičara o riječkoj izložbi kao o „,... najbitnijoj likovnoj manifestaciji Kraljevine". ${ }^{55}$ Ovi tekstovi redom su isticali poziciju Rijeke kao „... budnog stražara istočne granice” - mjesta na kojem su se susretali, integrirali i aktivirali relevantni kontakti. ${ }^{56}$ Izložba je tako poslužila kao povod isticanju transverzale koja od Italije, kao vodećega rasadnika kulture, preko grada Rijeke vodi u ,promociju transadriatiche", novih umjetničkih upliva prema podunavskim zemljama. Upravo u ovom se smislu Rijeka isticala kao „... moralni pobjednik, bastion s ulogom stražara koji čuva mjesto razmjene vrhunskih nematerijalnih vrijednosti civilizacije". ${ }^{57}$ Novine su prenijele dijelove ili cijeli govor koji je pri zatvaranju izložbe održao Riccardo Gigante, a $\mathrm{u}$ kojem se vrlo nadahnuto angažirao u isticanju navedenih stavova. Brojni popratni članci, osvrti i pregledi objavljeni su nakon ceremonije zatvaranja u tiskovinama šire regije. Tako o izložbi pozitivno piše Domenico Vaccari iz lista Tre Venezie i zagrebačka novinarka Alma Babić. ${ }^{8}$ Odjeci su bili vidljivi i u jugoslavenskom tisku te brojnim madarskim listovima. ${ }^{59}$

Druga medunarodna riječka umjetnička izložba prema dostupnim je podacima uvjerljivo najveća likovna smotra ikada održana u gradu Rijeci do današnjih dana. Na njoj je bilo izloženo gotovo tisuću umjetničkih djela iz međunarodne selekcije. Predmetna je izložba bila doista velika, i to ne samo po broju izložaka nego i po zastupljenosti medunarodno priznatih autora. Potaknuti od vlasti i uz nepodijeljenu opću potporu, organizatori su tako imali mogućnost u djelo sprovesti ideju da se cijela školska zgrada doslovno isprazni, da se svi zidovi presvuku tkaninom neutralne boje i da se nabavi nova galerijska oprema kako bi se postigli što bolji tehnički uvjeti za izlaganje radova, a manifestaciji osigurali svi potrebni preduvjeti za uspjeh.
Velike međunarodne izložbe kojima je Rijeka bila domaćin zauzimaju u galerijskoj aktivnosti između dvaju ratova iznimno mjesto. Izložbe koje su se održale 1925. i 1927. godine bile su bez sumnje veliki umjetnički događaji koji su važnošću prevladali regionalni karakter. Prva od njih, kao repriza Rimskoga bijenala, organizirana u Rijeci s puno entuzijazma, napora i uz široku društvenu potporu, nije zabilježila znatniji odaziv publike. Rezultati ovog istraživanja ilustriraju uspješnost napora u buđenju interesa, ukupne promocije likovne umjetnosti te senzibilizacije i edukacije riječke publike. Oni su uvjerljiv dokaz o utjecajima višegodišnjih upornih i predanih likovnih aktivnosti ne samo na užu, stručnu likovnu publiku nego i na ukupnu društvenu klimu grada te istaknuti riječki urbani specifikum - visoku opću razinu likovne osviještenosti kao dijela socijalnoga okružja. Već ova prva važna izložba koja se nakon aneksije organizirala u Rijeci, s osamsto probranih likovnih izložaka, donijela je dotad likovno zatvorenoj i globalno skromnoj sredini susret s vodećim talijanskim majstorima onoga doba, omogućila upoznavanje novih likovnih pristupa, izraza i tehnika, otvorila vrata u svijet novoga, prosperitetnog i nepoznatog.

Zašto se nije nastavila praksa bijenalnih riječkih izložbi nakon 1927. godine pitanje je na koje nije jednostavno dati utemeljen odgovor. S jedne strane, upravo u godinama nakon 1924., aneksija je bila važan politički, a onda i financijski poticaj, dok se, s druge strane, Bijenale u Rimu naprasno prestao održavati, pa se nije mogla nastaviti praksa njegova planiranog repriziranja u Rijeci, kako pokazuje Druga međunarodna umjetnička izložba. No bez obzira na uvjetovanosti i nemogućnost pretpostavke kakav bi tijek ovih velikih izložbi u Rijeci bio da se Rimski bijenale i dalje održavao, polet koji se nakon 1924. godine u likovnom životu grada osjetio, koji su inaugurirale izložbe 1925. i 1927. godine, nedvojbeno je bio potaknut aneksijom, a nastavio se drugim oblicima i manifestacijama u visokoj i iznimno produktivnoj praksi sve do okončanja talijanske vlasti. Nakon svih iznesenih činjenica i argumenata bilo bi utemeljeno zaključiti kako je talijanska vlast u Rijeci u području likovnosti, uz dugoročne i neizbrisive povoljne utjecaje, urodila pozitivnim, poticajnim i iznimno vrijednim plodovima. ${ }^{60}$

Prateći dostupne izvore, do prodora talijanskih utjecaja u grad Rijeku, likovna izlagačka djelatnost je skromna, a same izložbe povremene. Kako 
se ne bi stekao pogrešan dojam u interpretaciji, navedeno je daleko od potpore i glorifikacije talijanskih geostrateških pozicija i imperijalističkih težnji. U sumiranju raspoloživih podataka čini se razvidnim kako primarna namjera ovako poticajnoga utjecaja Italije na likovnost Rijeke nije bila altruistička, nego se ona primarno nalazi u namjeri što potpunije i brže funkcionalne integracije naših krajeva u Italiju, asimilaciji riječkoga hrvatskoga kulturnog prostora, a rastom utjecaja fašističkoga pokreta i u promociji ideje ove zloglasne ideologije. Upravo je ona u svijetu likovnosti donijela suptilno isticanje nasljeđa stare rimske civilizacije te poticanje ponosa pripadnosti Rijeke ,velikom talijanskom narodu”, a koje se iskazivalo upravo i integracijom lokalnih likovnih stvaralaca u širi talijanski likovni krug. Obrađeni materijali donose odgovore na neka otvorena pitanja te istodobno postavljaju platformu za buduća istraživanja usmjerena definiranju odgovora na dvojbe koje proizlaze iz iznesenih rezultata.

\section{BILJEŠKE}

1 Ovaj je rad proizašao iz dijela doktorske disertacije: Branko Metzger-Šober, ,,Međuratni povijesni kontekst osnivanja Galerije likovnih umjetnosti u Rijeci.”, Sveučilište u Zadru, 2016. https://dr.nsk.hr/islandora/object/unizd\%3A1096/.

2 Pojedini riječki autori: Daina Glavočić, Igor Žic, Ervin Dubrović, Branko Franceschi, Julija Lozzi-Barković, Irvin Lukežić i dr. analizirali su individualne i grupne izložbe likovnih umjetnika ili su sudjelovali u projektima koji su promovirali određeno razdoblje riječke prošlosti.

3 Razdoblje obilježeno vladavinom talijanskoga pjesnika, romanopisca, dramatičara i borca za Veliku Italiju Gabrielea D’Annunzija. Započelo je Pohodom iz Ronchija 11. rujna 1919. godine, ulaskom u Rijeku 12. rujna 1919. i trajalo je do 18. siječnja 1921. godine.

4 „L'Esposizione d'Arte,” La Vedetta d'Italia, Fiume, 17. lipnja 1925., 2.

5 „L'Esposizione d'Arte,” 2.

6 Danas je u ovoj zgradi smještena osnovna i srednja talijanska škola u Rijeci, na adresi E. Barčića 6.

7 „L’Esposizione di Belle Arti della città di Fiume,” La Vedetta d'Italia, Fiume, 21. lipnja 1925., 2.

8 „Prima Esposizione Fiumana di Belle Arti," La Vedetta d'Italia, Fiume, 24. srpnja 1925., 2.

9 Pohod iz Ronchija na Rijeku pokrenut je kao iskaz D'Annunzijeva nezadovoljstva ishodom Prvoga svjetskog rata, kao i milijuna drugih Talijana. Ronchi je bio polazište pobunjenika koji su D'Annunzija proglasili svojim zapovjednikom. Legija od oko 15000 odanih vojnika i avanturista krenula je 11. rujna 1919. godine prema Rijeci, u koju ulaze dan poslije.

10 Prema dostupnim podacima maestro Pietro Mascagni trebao je biti dirigentom opera: Isabeau Andrea Cheniera, Barbiere di Seviglia Giochina Rossinija i Tosce Giacoma Puccinija. „Prima Esposizione,” 2.

11 „Prima Esposizione,” 2.

12 „L'Esposizione di Belle Arti,” 2.

13 „Sotto il patronato del Municipio di Fiume viene inaugurata la prima Esposizione di Belle Arti," La Vedetta d'Italia, Fiume, 25. kolovoza 1925., 2.

14 „Sotto il patronato,” 2.

15 A. Chioggia, ,All'Esposizione internazionale di Belle Arti Pittori italiani, jugoslavi e ungheresi," La Vedetta d'Italia, 30. kolovoza 1925., 2.

16 A. Chioggia, G. Raimondi, „All'Esposizione internazionale di Belle Arti - La mostra dei pittori fiumani e di Carlo Carra," La Vedetta d'Italia, Fiume, 28. kolovoza 1925., 2.

17 Chioggia, Raimondi, „All'Esposizione,” 2.

18 Daina Glavočić, Riječka likovna situacija 1920. - 1940. Fijumani - riječka situacija 1920. - 1940. (Rijeka: Muzej moderne i suvremene umjetnosti, 2007.), 54.

19 Carlo Carrà je na ovoj riječkoj izložbi izložio sljedeće radove: Le figlie di Lot, Donna al Balcone (simultaneita plastica), La fanciulla dell'Ovest, Tramonto sui monti, Festival, Autunno, S. Gaudenzio di Varallo, Paese, Casine, Crevola, Sasine sul Sesia, Solitudine, Natura morta metafisica, La Casa dell'Amore, S. Giacomo di Varallo, Il lago, Chiesa romanica, Il Mastallone a Varallo, L'abbeveratoio, Cotonificio sul Sesia, Paesaggio, S. Gaudenzio di Varallo (studio), La Crevola (studio), Casette sotto il monte, Paesaggio, Studio di Paese, Ovale delle apparizion, Marina, L'amante dell'ingegnere, Il mulino di S. Anna.

20 Chioggia, „All'Esposizione,” 2.

21 U dvorani II bila je izložena velika sakralna kompozicija Antonija Discovolla La Croce, pejzaž Galilea Chinija, tri pejzaža Trajana Chitarinija, portret dame autora Andree Bologne i na kraju niz slika Don Angela Rescallija. U dvorani VII bila su izložena slikarska djela slikara s početka 20. stoljeća među kojima su se isticala dva Tosijeva pejzaža 
Zoagli i Vilminore, iznimno hvaljena tijekom III. bijenala u Rimu. Tu su još Ugo Bernasconi s djelom Cartoccio di frutta, Pietro Marussig s djelom Bambina i Natura morta, Alberto Salieti s velikom kompozicijom naziva Autunno. U dvorani VIII dominiralo je veliko slikarsko platno Antonija Someda Per te Italia. Romualdo Prati predstavio se slikom Pomeriggio d'autunno, Armando Barabino s Natura morta. U dvorani X izložene su slike Giovannija Lomija Siena, Piazza del campo i Duomo di Siena. Uz njega je bio izložen Autoritratto Antonija Piattija. U dvorani XII Vittore Zanetti-Zilla izložio je Chiesa del Redentore, Albero morto te Barconi davanti San Giorgio. Gino Romiti izlaže Sole nel mare i La luna sul mare, Giardino sul mare, zatim Domenico de Bernardi Strada campestre i Fino di maggio. Ovu je izložbenu dvoranu još obogatio i Giuseppe Guindani slikom La bimba e il Pierrot. U Sala dei pittori Napoletani isticala se La matassa autora Vincenza Irollija, dok je Giuseppe Casciaro privlačio pozornost poznatim napuljskim pejzažima, slično kao i autori Vincenzo Caprile, Arnaldo Lisia, Vincenzo Colucci i La Bella s djelom Vecchia Napoli. Ova je dvorana ugostila i autora Vicenza Caprilea, čiju su izloženu sliku Rio della Canonica a Venezia popratile pozitivne kritike. U Sali Venezia Giulia izložene su slike La servolana i Ritratto di giovine donna Gina Parnija, djelo Sciarra-Sciat Guida Grimanija, Il Carso Uga Flumianija, Mattino, Marina Fernanda Neulliana, dva akvarela Giorgia De Wolfa i zimski pejzaž Virgilija Fresca. Osim ovih slikara, u Sali Venezia Giulia ovom su prilikom još bile i izložene slike Gilde Pansiotti Cambon, Glauca Cambona i Edgarda Samba. Chioggia, „Pittori italiani, jugoslavi e ungheresi,” 2.

22 Chioggia, ,All’Esposizione,” 2.

23 U kataloškom dijelu prikaza sudjelovanja jugoslavenskih autora na izložbi, a koji nisu navedeni kroz dnevni tisak navode se i sljedeći autori: Bela Čikoš Sesija (3 rada), Menci Clement Crnčić (3 rada), Izidor Kršnjavi (1 rad), Radivoj Krainer (4 rada), Ivan Moretti Zajc (3 rada), Marko Rašica (1 rad), Ivan Tišov (2 rada), Rudolf Valdec (3 rada), Slavko Tomerlin (1 rad), Juraj Škarpa (2 rada), Anđeo Uvodić (1 rad). Prima Esposizione Fiumana Internazionale di Belle Arti, Fiume (Fiume: Stabilimento Tipografico de la Vedetta d'Italia, S.A.1925.)

24 Chioggia, „All'Esposizione,” 2.

25 Chioggia, „All'Esposizione,” 2.

26 Chioggia, „All'Esposizione,” 2.

27 Chioggia, „All'Esposizione,” 2.

28 Među uvaženim posjetiteljima koji su tijekom svoga posjeta gradskoj upravi posjetili i ovu manifestaciju dnevni tisak izdvojio je posjet u ime talijanske vlade S. E. Carusija koji je u pratnji prefekta E. Vivorija, Marija de Hajnala, slikara Carla Ostrogovicha i Umberta Gnate obišao izložbu 14. rujna 1925. godine. „Esposizione di Belle Arti - La visita di S. E. Carusi," La Vedetta d'Italia, Fiume, 15. rujna 1925., 2.

29 Otkupi umjetnina na spomenutoj izložbi išli su u nekoliko pravaca, od onih privatnih poput otkupa brončanog bareljefa Rudolfa Valdeca Re Alessandro I. e Regina Maria (otkupili kralj Aleksandar Karađorđević i kraljica Marija), do donatorskih poput otkupa slike Umberta Gnate Baccante (otkupio Umberto Tedesco iz Napulja) i slike Domenica Someda Per te, Italia! (comm. Pive za grad Rijeku). Djela otkupljivana donacijama trebala su potaknuti gradsku vlast na osnivanje Galerije umjetnosti kao institucije od strateške usmjerenosti i širenja talijanskih utjecaja put istoka i sjeveroistoka.

30 „Esposizione di Belle Arti,” La Vedetta d'Italia, Fiume, 27. rujna 1925., 2.

31 Chioggia, Raimondi, „All’Esposizione,” 2.
32 „Esposizione internazionale di Belle Arti,” La Vedetta d'Italia, Fiume, 27. svibnja 1927., 3.

33 Za razliku od 1925. godine, slike za ovu izložbu nisu preuzete s Esposizioni Biennali d'Arte a Roma. Nakon tri održana bijenala u Rimu, i to 1921., 1923./24. i 1925. od kojih je ovaj zadnji bio međunarodnog karaktera, više nema tragova o kasnijem održavanju iste manifestacije.

34 „La nostra II.a Esposizione di Belle Arti,” La Vedetta d'Italia, Fiume, 4. lipnja 1927., 2.

35 „Esposizione Internazionale di Belle Arti della Citta di Fiume," La Vedetta d'Italia, Fiume, 19. lipnja 1927., 2.

36 „La seconda esposizione internazionale d'arte,” La Vedetta d'Italia, Fiume, 14. srpnja 1927., 2.

37 „La seconda esposizione,” 2.

38 „La seconda esposizione," 2.

39 „L'Esposizione di Belle Arti,” La Vedetta d'Italia, Fiume, 4. kolovoza 1927., 2.

40 Izložba je bila organizirana u zgradi na današnjoj adresi Dolac 1, u sadašnjim prostorima Sveučilišne biblioteke, Glagoljaške zbirke i nekadašnjega Muzeja moderne i suvremene umjetnosti.

41 „L'Esposizione di Belle Arti,” La Vedetta d'Italia, Fiume, 7. kolovoza 1927., 2.

42 „L'inaugurazione dell'Esposizione - Un importante discorso di S. E. Martelli," La Vedetta d'Italia, Fiume, 6. kolovoza 1927., 2.

43 „L'esposizione di Belle Arti,” La Vedetta d'Italia, Fiume, 8. kolovoza 1927., 2.

44 „L'esposizione di Belle Arti,” 2.

45 „L'esposizione di Belle Arti,” 2.

46 „L'esposizione di Belle Arti,” 2.

47 „L'esposizione di Belle Arti,” 2.

48 Ulaznice koje su služile kao glasački listići bile su ujedno i srećke. Šestogodišnjaci Aldo i Anita Kalani izvukli su ovom prigodom dobitnike nagrada pa je tako prvonagradeni rad procijenjen na 1600 lira, pastel Nudo Róze Jokai, dobio vlasnik ulaznice broj 2842, vlasnik ulaznice 2574 dobio je drugonagrađeni rad procijenjen na 800 lira, djelo Marcela Ostrogovicha La laguna, a vlasnik ulaznice 1279 dobio je treću nagradu, Herendov porculan procijenjene vrijednosti 200 lira. Nakon završetka izložbe i promocije dobitnika nagrada, tri su navedena rada bila još neko vrijeme izložena u posebnoj vitrini na riječkom Korzu. Iz dostupnih izvora naknadno doznajemo kako je prvonagrađeni rad mađarske umjetnice Róze Jokai isporučen za stalni postav Camere di Commercio e Industria s obzirom na to da ga dobitnik nije preuzeo. „Alla Biennale d'Arte,” La Vedetta d'Italia, Fiume, 30. kolovoza 1927., 2.

49 Među uglednim posjetiteljima izložbe bio je generalni tajnik Akademije lijepih umjetnosti iz Budimpešte, Desiderio Pilch koji se odazvao pozivu tajnika izložbe Marija de Hajnala i Ottonea Servazzija, koji je vodio ured za tisak. Uvaženi se posjetitelj prema bilješkama dugo zadržao u razgledavanju izložbe, a potom je istaknuo njezinu važnost i svoje zadovoljstvo zbog mogućnosti uživanja u radovima najboljih talijanskih umjetnika. Istoga dana izložbu je posjetio i Francesco Herceg, predsjednik Savjeta lijepih umjetnosti iz Budimpešte. U tisku se nadalje spominje da je izložbu posjetio i Emanuele Vivorio, prefekt Kvarnerske provincije koji u izjavama nije štedio riječi pohvale i izraze oduševljenosti, kao i generalni konzul Kraljevine Mađarske Stefano Reviczky, konzul kraljevine Jugoslavije Dobricic koje je izložbom sproveo Milutin P. Mihanovich, slikar jugoslavenske kraljevske kuće. „Alla Biennale di Belle Arti,” La Vedetta d'Italia, Fiume, 4. rujna 1927., 2.

50 Izvješća $u$ dnevnom tisku o događanjima na 2 . 


\section{REFERENCES}

međunarodnoj umjetničkoj izložbi prate otkupe umjetničkih djela. U ovome slučaju uglavnom se radi o otkupima privatnih kolekcionara bez naznaka donatorskih gesti. Zanimljivo je da je rad Marija de Hajnala Spavento otkupljen za kraljevsku obitelj Italije.

51 „La cerimonia della chiusura della Biennale d'Arte,” La Vedetta d'Italia, Fiume, 9. rujna 1927., 2; „La chiusura della Biennale - Un quadro di artista fiumano acquistato dalla Casa Reale," La Vedetta d'Italia, Fiume, 8. rujna 1927., 2.

52 „Alla Biennale d'Arte,” La Vedetta d'Italia, Fiume, 27. kolovoza 1927., 2.

53 „Gli artisti italiani alla 2.a Esposizione Internaz. di Belle Arti," La Vedetta d'Italia, Fiume, 2. kolovoza 1927., 2.

54 Miclavio, „Echi della Biennale d'Arte - Interessamento della stampa jugoslava,” La Vedetta d'Italia, Fiume, 21. rujna 1927., 3 .

55 „La ceremonia della chiusura della Biennale d'Arte,” La Vedetta d'Italia, Fiume, 9. rujna 1927., 2.

56 „Domani si chiude la Biennale d'Arte,” La vedetta d'Italia. Fiume, 7. rujna 1927., 2.

57 „Domani,” 2

58 „La ceremonia,” 2

59 Miclavio, „Echi della Biennale d'Arte - Interessamento della stampa jugoslava," La Vedetta d'Italia, Fiume, 21. rujna 1927., 3."

60 Talijanski utjecaji na likovnu scenu Rijeke i okolice očitovali su se i u osnivanju umjetničkoga sindikata, njegovim anualnim izložbama, pa time i otvaranjem mogućnosti sudjelovanja riječkih likovnih umjetnika na ostalim sindikalnim izložbama diljem Kraljevine Italije. Otvaranjem europske likovne scene nekim je riječkim autorima omogućilo postizanje iznimne inozemne karijere. Tako je Ladislao de Gauss imao zapažen nastup na Venecijanskom bijenalu 1936. godine, baš kao i Enrico Fonda u Parizu 1927. godine na Jesenskom salonu. Potonji je autor, prepoznat $\mathrm{u}$ europskim krugovima likovne struke, nastavio život $\mathrm{i}$ rad u Parizu te se svrstao u red vodećih europskih slikara čija su djela danas prisutna u stalnom postavu umjetničke kolekcije slika Centra Pompidou u Parizu. Riječanin Carlo Ostrogovich je nakon uspjeha u Rijeci nastavio karijeru u Milanu te se uključio u red vodećih talijanskih slikara svoga vremena.
Arh, Branka and Glavočić, Daina. Vilim Svečnjak. Zagreb: Galerija Mona Lisa, 2006.

Drenig, Francesco. Fotografije / fotografie. Exhibition catalogue. Rijeka: Muzej grada Rijeke, Rim: Società di studi fiumani, 2013.

Hrvatska moderna (izložba djela iz fundusa, 1881. - 1943.). Moderna galerija Rijeka, 15. VI. - 15. IX. Edited by Daina Glavočić. Rijeka: Moderna galerija Rijeka, 1992.

Glavočić, Daina. Romolo Wnoucsek Venucci. Rijeka: Moderna galerija Rijeka, 1996

Glavočič, Daina. Ladislao de Gauss: riječki međuratni slikar pitore fiumano tra le due guerre. Rijeka: Moderna galerija, 1999.

Glavočić, Daina. Carlo Ostrogovich 1884. - 1962. Rijeka: Moderna galerija Rijeka - Muzej moderne i suvremene umjetnosti, 2002.

Glavočić, Daina. Romolo Venucci: crteži, studije i plakati iz zbirke - disegni, studi e manifesti provenienti della collezione: 1920. - 1950. Rijeka: Moderna galerija - Muzej moderne i suvremene umjetnosti, 2002.

Lukežić, Irvin. Fijumanske priče. Rijeka: Izdavački centar Rijeka, 1991.

Lukežić, Irvin. Riječke glose - opaske o davnim danima. Rijeka: Izdavački centar Rijeka, 2004

Metzger-Šober, Branko. "Međuratni povijesni kontekst osnivanja Galerije likovnih umjetnosti u Rijeci." PhD diss., University of Zadar, 2016, https://dr.nsk.hr/islandora/object/unizd\%3A1096/

Moravček, Goran. Rijeka: prešućena povijest. Rijeka, 1990.

Prima Esposizione Fiumana Internazionale di Belle Arti, Fiume. Exhibition catalogue. Fiume: Stabilimento Tipografico de La Vedetta d'Italia, S.A.1925.

Seconda Esposizione Internazionale di Belle Arti della citta di Fiume. Exhibition catalogue. Fiume: Stabilimento Tipografico de La Vedetta d'Italia, S.A.,1927.

Žic. Igor. Rijeka, grad Sv. Vida. Rijeka: Dušević \& Kršovnik, 1996.

Žic, Igor. Riječki orao, venecijanski lav i rimska vučica. Rijeka: Adamić, 2003. 


\section{SUMMARY}

\section{Biennial Art Exhibitions in Rijeka in 1925 and 1927}

The paper focuses on two of the many exhibiting activities in Rijeka in the period following the Treaty of Rome, interpreted in the context of current regional, Italian state and wider European political circumstances. A systematic analysis of art exhibitions in Rijeka held in 1925 and 1927, determined by socio-political circumstances through the variety of artistic expressions of an extremely broad and diverse number of artists, prompts a reflection on the general neglect of Rijeka as a city in stagnation in the interwar period, following the arrival of the Italian authorities. The interpretation of the circumstances in which artists presented their work to the audience, the exhibition venues of these activities, as well as the importance of these biennial art exhibitions and their causality in the discussed sequence, provide elements that suggest a change of such a paradigm.

These two international exhibitions held in Rijeka certainly occupy an exceptional place among exhibiting events in the interwar period. The first of these, as a rerun of the Third Roman Biennale, provided the artistically closed and globally modest environment with the opportunity to meet the leading Italian artists of the period and to get acquainted with new artistic approaches, expressions and techniques. According to available data, the second international exhibition organized in 1927 was by far the largest art show ever held in Rije$\mathrm{ka}$, to this day. The exhibition was indeed large, not only in number of exhibited artworks, but also considering the presence of internationally renowned artists and the extremely advanced criteria applied in the selection of works, which then ensured the highest level of quality of the event itself. The reasons of discontinuation of major exhibition events in Rijeka after 1927 are difficult to explain.

Dr. sc. BRANKO METZGER-ŠOBER diplomirao je na studiju Likovne kulture Pedagoškog fakulteta Sveučilišta u Rijeci. Doktorski rad na temu Meduratni povijesni kontekst osnivanja Galerije likounih umjetnosti $u$ Rijeci obranio je 2016. godine na poslijediplomskom doktorskom studiju Humanističke znanosti Sveučilišta u Zadru. Radi kao slobodni istraživač objavivši do sada nekoliko stručnih i znanstvenih radova na temu valorizacije kulturne baštine.
BRANKO METZGER-ŠOBER, PhD, received his MA in Visual Culture from the Faculty of Teacher Education of the University of Rijeka. In 2016 he obtained his PhD from the Postgraduate Doctoral Study Programme in the Humanities, University of Zadar, with the thesis entitled The Interwar Historical Context of the Establishment of Gallery of Fine Arts in City of Rijeka. As an independent researcher he has published several professional and scholarly papers related to the topic of cultural heritage assessment. 